\title{
The Spillover Effects of Fed's Policies with Emphasis to the Fragile Five
}

\author{
Mehmet ORHAN, *Zehra Vildan SERIN, Halil İbrahim ÇELİKEL \\ Department of Economics, Fatih University, Istanbul, Turkey \\ *morhan@fatih.edu.tr
}

\begin{abstract}
Since the Bretton Woods Agreement, the U.S. dollar has played the role of dominant global currency. As a result, the Federal Reserve Bank has many privileges such as the ability to run trade deficits without foreign exchange reserves. In the world, foreign exchange rates of currencies are quoted against the dollar, and majority of currency trading involves the dollar. Besides, international trade in primary commodities, such as oil, wheat, gold and coffee are bought and sold in U.S. dollar. The central banks of countries hold major positions of their international reserves in dollars. Any changes in its interest rates automatically alter the revenues of all world assets. With deregulated financial markets, the spillover effects of the Federal Reserve Bank's decisions have increased. In this paper, we examine the impacts of Federal Reserve Bank policies over the Fragile Five that is a sub group of the weaker emerging markets namely Brazil, India, Indonesia, South Africa and Turkey. We are mainly focusing on the consequences of changes in Fed's policies on the fragile five's basic indicators; exchange rate, interest rate, and the stock exchange indices. All Fragile Five currencies have been depreciated by about 10 to $25 \%$ after the Fed tapering decisions. In addition we test for mean and volatility spillover of Wall Street on stock exchange indices of the Fragile Five in GARCH in mean framework and document the existence of such spillovers in almost all cases.
\end{abstract}

Keywords: Global Financial Crisis, Tapering, Fragile Five, Quantitative Easing, Emerging Economies, FED, GARCH in Mean

\section{Introduction}

A careful and close look at monetary history reveals that international monetary system changes every 30 to 40 years. Between 1873 and 1900, only the Gold Standard System dominated in the world. Under this system every banknote in circulation could exchange by an equivalent amount of gold, so it was one hundred percent backing. During World Wars I and II, all countries in Europe left the Classical Gold Standard and started issuing banknotes. With the Bretton Woods Agreement, the Fed achieved its hegemonic position among the Western Economies and then only the US dollar remained convertible into gold and other participant countries' currencies were fixed to the dollar. After that, the U.S. dollar became the central reserve currency between 1944 and 1971 so all currencies were pegged to gold but through the US dollar. This system entirely collapsed in 1973 because of the growing US current account deficit and the speculative pressure on the dollar following the rise in U.S. inflation. Since March 1973, exchange relationship between gold and dollar was abandoned. Another agreement is signed between the US and Saudi Arabia in June 1974 and since then all oil has been sold and bought in US dollars (Gökay, 2009). With this agreement U.S. dollar regained its function as the international reserve currency in the world economy and petro-dollars sent back into the US economy as investments in US treasury notes, stocks, mutual funds and bonds. As a result, more than $60 \%$ of foreign reserves are held in dollars (Eichengreen, 2013). Therefore the Federal Reserve Bank's (Fed) decision has contributed to greater capital flows (Serin \& Oktay, 2013). Following the Fed, Bank of Canada and European Central Bank started to apply similar unconventional measures in order to maintain monetary flows and market stability (Albu et al., 2014)

After the 2007- 2008 global financial crisis the Fed began to apply an unconventional monetary policy in order to stimulate the economy while keeping the interest rates record low. Fed launched a new set of non-standard policy tools which have been known as Quantitative Easing policies (QE). The Fed had cut interest rates at or close to the zero bound to increase access to credit and liquidity. First stage of QE policies was referred as QE1 which was announced in 2008. The Fed had kept policy rates at 0 to 0.25 percent since December 2008; Fed measures between 2008 and 2010 were highly effective in lowering sovereign yields and raising equity markets especially in the US relative to other countries (Fratzscher et al., 2013). Second stage of Fed policies (QE2 policies) was announced in 2010, in order to provide additional stimulus to the economy. During this period, many emerging economies had received large 
capital inflows. Capital inflows to emerging economies peaked in January 2013. QE policies caused an explosion of Fed's balance sheet from $\$ 900$ billion prior to the Lehman Brother collapse to more than $\$ 4$ trillion (Subramanian, 2014).

In mid-May, 2013, FED Chairman Bernanke announced the radical change in Fed policies and announced that they would reduce large scale asset purchases and raise short term policy interest rate. The current Fed Chair, Janet Yellen indicated that the Fed will be following the same strategy. These tapering announcements had a sharp negative impact on emerging markets. Some emerging countries had witnessed sharp capital flow reversals (Nechio, 2014). However emerging economies' reactions to the Fed's "tapering talks" were not uniform. The impacts of the Fed tapering news on emerging markets depend on their macroeconomic fundamentals. Specifically emerging economies that have twin deficits faced large currency depreciations when interest rate expectations for advanced economies tightened. If a country has current account deficit, it will consume and invest more than its production and it will accumulate a negative net foreign asset position with other countries. News of tapering made changes in policy expectations of the Fragile Five associating with much larger exchange rate depreciation, drops in stock markets and increases in bond indices (Nechio, 2014). The "Fragile Five" symbolizes emerging market currencies under the most influential pressure against the U.S. including Brazil, India, Indonesia, South Africa and Turkey. They are heavily dependent on short term foreign investment both to finance their economic growth and their current account deficit (Barkar, 2013). This paper examines the effects of Fed policies over the Fragile Five. It is arranged in 6 sections the first of which is the Introduction. Section 2 addresses related literature. Section 3 elaborates on the impact of Fed policies in comparison to various developing and advanced economies whereas Section 4 overviews the impact of Fed policies on the Fragile Five. Section 5 establishes the GARCH in mean framework to figure out the existence of mean and volatility spillover effects and finally Section 6 concludes.

\section{Literature Review}

The Fed started to apply unconventional monetary policy after the global financial crisis and 2008 recession. The literature concerning the effects of quantitative easing policies on various aspects of financial markets is extensive. Ex-Chairman of the Fed, Bernanke, started to apply easy monetary policies and left to follow Taylor's rule which is developed by the Stanford economist John Taylor ${ }^{1}$. Main objective of is the conventional monetary policies is inflation targeting. ${ }^{2}$ In the conventional policy regime, the central bank sets the short-term interest rate as its policy instrument in response to macroeconomic shocks associated with inflation and the output gap. However, in the unconventional policy regime, the central bank expands its balance sheet under zero lower bound (Kimura \& Nakajima, 2013). Unconventional policies can be classified into 'quantitative easing' and 'credit easing', depending on whether the central bank focuses on the liability side or the asset side of its balance sheet. The primary tools used by the central bank are changes in the prime interest rate, changes in the amount of money in circulation and changes in the reserve requirements for banks. Obstfeld and Rogoff (2002) and Clarida et

\footnotetext{
1 Specifically, the rule states that the "real" short-term interest rate (the interest rate adjusted for inflation) should be determined according to three factors concerning: (1) Where actual inflation is relative to the targeted level that the Fed wishes to achieve, (2) How far economic activity is above or below its "full employment" level, and (3) What the level of the short-term interest rate consistent with full employment would be. The rule "recommends" a relatively high interest rate (that is, a "tight" monetary policy) when inflation is above its target or when the economy is above its full employment level, and a relatively low interest rate ("easy" monetary policy) in the opposite situations: Taylor, John B. (1993). "Discretion versus Policy Rules in Practice," Carnegie-Rochester Conference Series on Public Policy, 39, pp. 195-214.http://www.frbsf.org/education/publications/doctor-econ/1998/march/taylor-rulemonetary policy.

2 It contains five main elements: 1) Public announcement of medium-term numerical targets for inflation; 2) Institutional commitment to price stability as the primary goal of monetary policy, to which other goals are subordinated; 3) Information inclusive strategy in which many variables, and not just monetary aggregates or the exchange rate, are used for deciding the setting of policy instruments; 4) Increased transparency of the monetary policy strategy through communication with the public and the markets about the plans, objectives, and decisions of the monetary authorities; and 5) Increased accountability of the central bank for attaining its inflation objectives (Mishkin,2010).
} 
al (2002) believe that nominal interest rates are adjusted with deviations of inflation. Fed measures in the early stage of the crisis were highly effective in lowering sovereign yields and raising equity markets, especially in the US relative to other countries (Fratzscher et al., 2013). They examine the effects of quantitative easing $(\mathrm{QE})$ policies in the United States on gross inflows to developing countries. Their results support that QE may have been transmitted through liquidity, portfolio balancing, and condense channels. These policies have contributed to greater capital flows and exchange market pressures in the emerging markets (EMs).

QE has also side effects for the US that may compound and complicate the initial problems (Wood, 2013). One side-effect of this financing policy is the rise in public debt. Thus in Europe, bond financed fiscal stimulus was reversed as public debt increased and instead 'fiscal austerity' was imposed. However, the "austerity" policies have failed to reach their objectives and, in fact, have proven to be counterproductive. Budget deficits and public debt have been under upward pressure, GDP has fallen, the public debt burden has risen, and unemployment has continued to grow to intolerable levels (Herbst et al, 2014). The most obvious effect of QE is seen in the balance sheet of the Fed. Between May 2008 and 2013, assets in the Fed have increased by 318\% (Carr, 2013). QE has weak effect on the US nominal GDP growth and stronger effect on labor participation in the US. However, if QE results only in improving banks reserve balances, and not in expanding bank credit to the real sector, the consequences will be very different from expansion policy (Herbst et al., 2014). Hoffman (2014) has complained about QEs and its zero bound' interest rate policies, because of creating financial asset bubbles globally and destabilizing in the global international monetary system. Also these dual Fed policies have become increasingly 'inefficient' while feeding financial speculation and asset bubbles, they have not resulted in much real investment in goods and services (Rasmus, 2013).

In particular, unconventional monetary policy in the US has invoked criticisms from emerging markets. Eichengreen and Gupta (2014), using daily data for exchange rates, foreign reserves and equity prices between April and August 2013 found that important determinant of the differential impact was the size of the country's financial market: countries with larger markets experienced more pressure on the exchange rate, foreign reserves and equity prices. Doh (2010), Gagnon et al. (2011), and D'Amico et al. (2012) found that the Fed's QE policy has significant effect on long term interest rate. Hancock and Passmore (2011) and Taylor (2012) explore the Federal Reserve's mortgage-backed securities purchase program, while Krishnamurthy and Vissing-Jorgensen (2011) focus on the entire "QE1" and "QE2" programs. Nechio (2014) showed the importance of improving domestic fundamentals as global monetary conditions return to normal to emerging countries. Herbst et al. (2014) explained how reserve traps can dampen the effectiveness of the QE on real sector recovery. This event is known as 'tapering', prompted a sharp, negative response from financial markets. The concomitant rebalancing of global portfolios away from emerging-market assets resulted in capital outflows and currency depreciations in several large emerging-market countries. Brazil, India, Indonesia, South Africa, and Turkey were particularly affected (Burns et al., 2014).

\section{The Impact of the Fed Policies on Selected Major Markets}

Since the global economic activities are integrated especially around the giant economies, the Fed policies have spillover effects over all countries. In this part of the paper our main concern is the effect of these policies, especially by the Fed, over some financial indicators of Japan, China, Russia and the European Union. We are mainly focusing on the exchange rate, stock exchange indexes and bond indices.

The Fed's Policies and Exchange Rates: Figure 1 displays the evolvement of the exchange rates of the EU Euro, Japanese Yen, Chinese Yuan and Russian Ruble. Yuan is consciously and insistently kept depreciated by the Chinese government to ease exports and mitigate imports to China. The exchange rate is almost fixed to the USD. This policy has been to the great advantage of China in terms of trade balance, growth and employment. This feature is traded over the stable evolvement of the Yuan. On the other hand, the Central Bank of Japan, namely the Bank of Japan (BoJ), has made an essential attack to devalue Yen in order to get out of the persistent recession. The Bank has increased the money supply tremendously and thus the Yen is depreciated against other currencies, especially the USD. In about 15 months' time the Yen is depreciated by about $20 \%$. The ECB is reluctant to make decisions, act and take positions due to the complex and cumbersome structure of the EU and her bureaucracy. 
Figure 1: The behavior of the exchange rates in response to Fed decisions, EU Euro, Japanese Yen, Chinese Yuan and the Russian Ruble

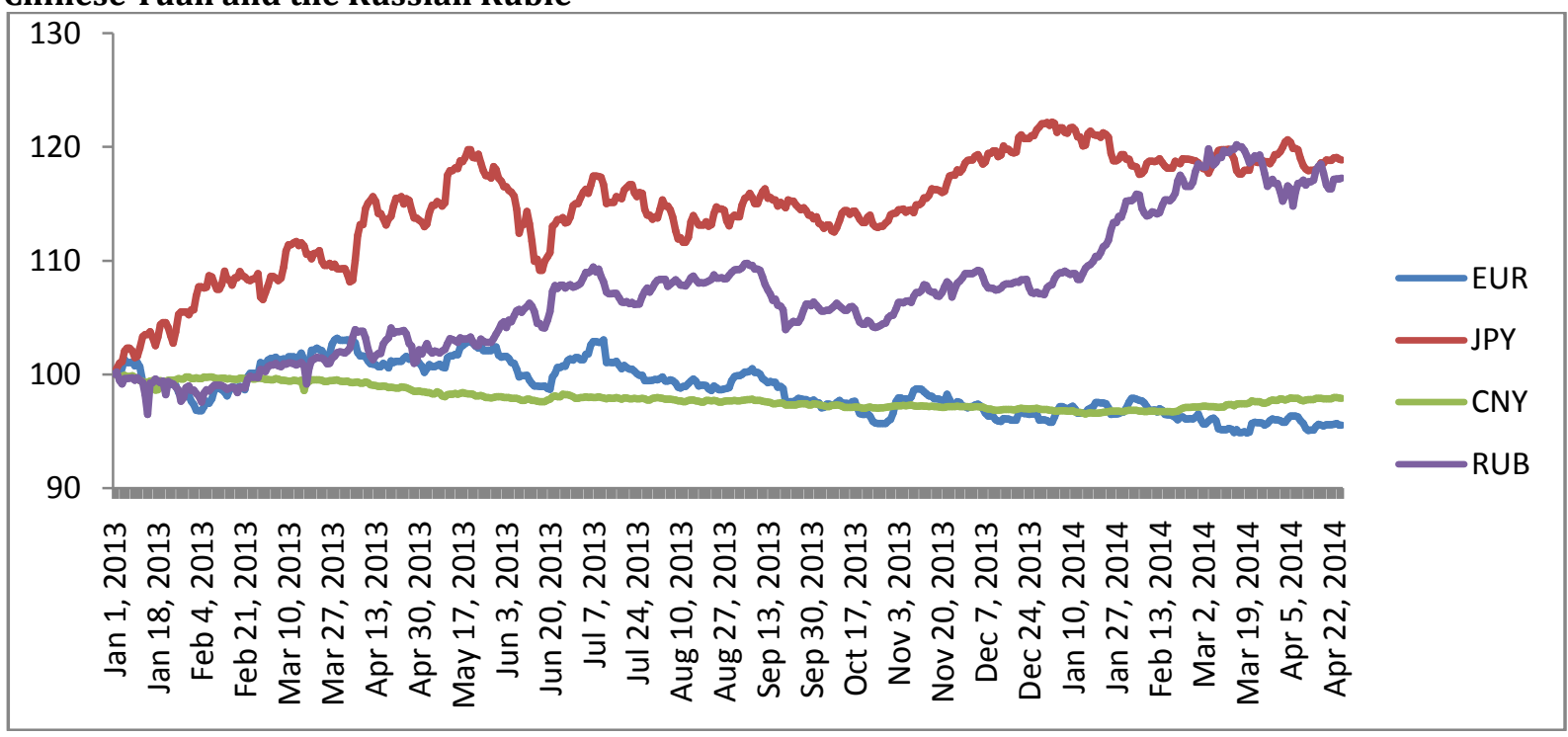

The Fed's Policies and Stock Exchange Index: We plot the stock exchange indices of both China and Russia in Figure 2. At the end of 15 months duration the Russian index falls by about $25 \%$ whereas the Chinese index falls by about 10\%. One has to keep in mind that the sharp fall at the beginning of 2014 April is due to the tension in Ukraine and Crimea. Although the two indices fall apart, they follow similar trajectories that decline after mid 2013 more rapidly. The plots reveal that the great recession is disadvantageous to both countries, especially to Russia whose economy heavily depends on

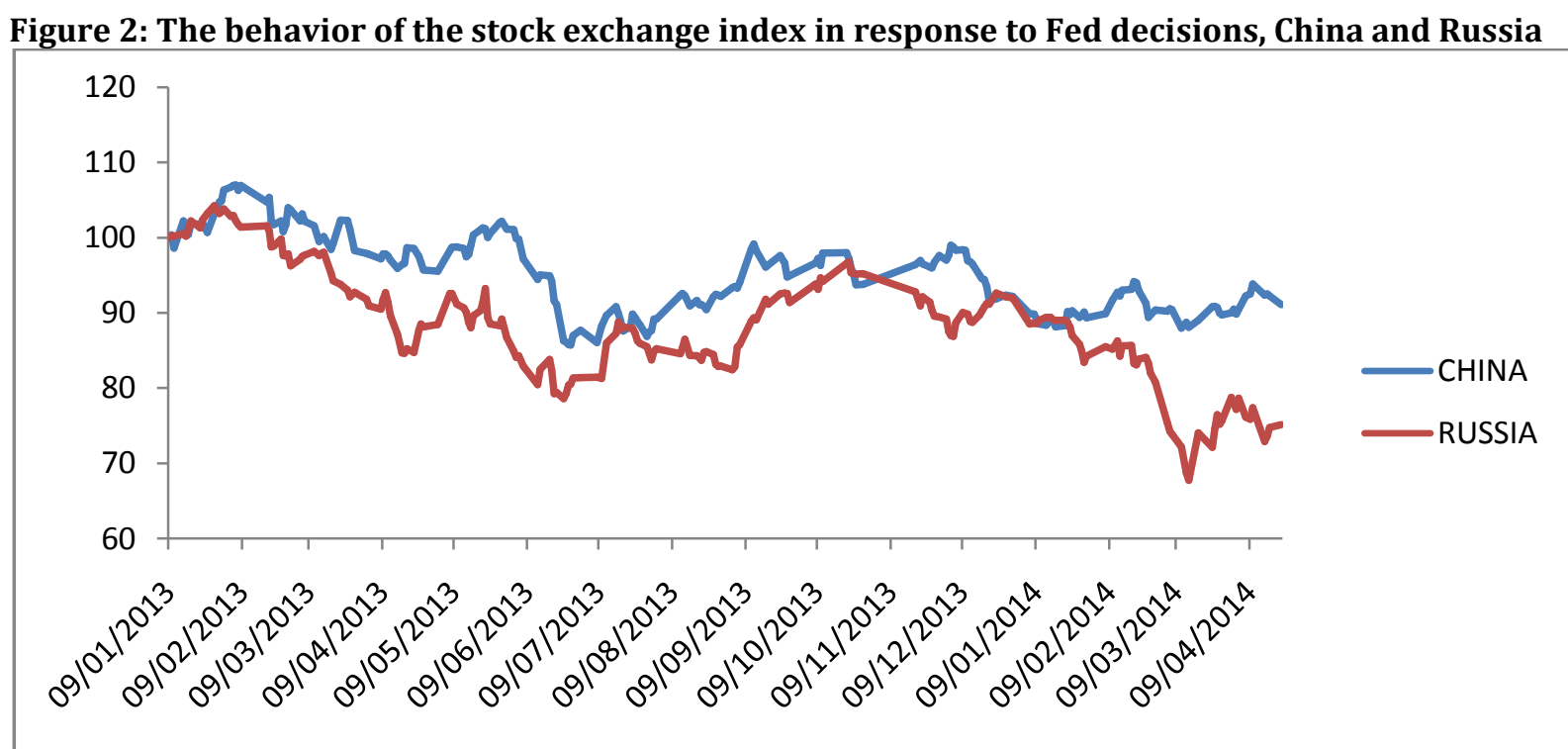

Countries including USA, Germany, France and Spain have followed similar paths. We have included Spain to observe the EU giant with high public debt/GDP ratio. Spain have done close to others as long as the tapering period is concerned. From the beginning of 2013 after tapering to April 2014; the Japanese stock exchange index goes far beyond the rest due to the considerable expansionary monetary policy. It ends up with about 35\% increase although there was occasional 50\% increase around January 2014. 
Figure 3: The behavior of the stock exchange index in response to Fed decisions, USA, Japan, Germany, France, and Spain

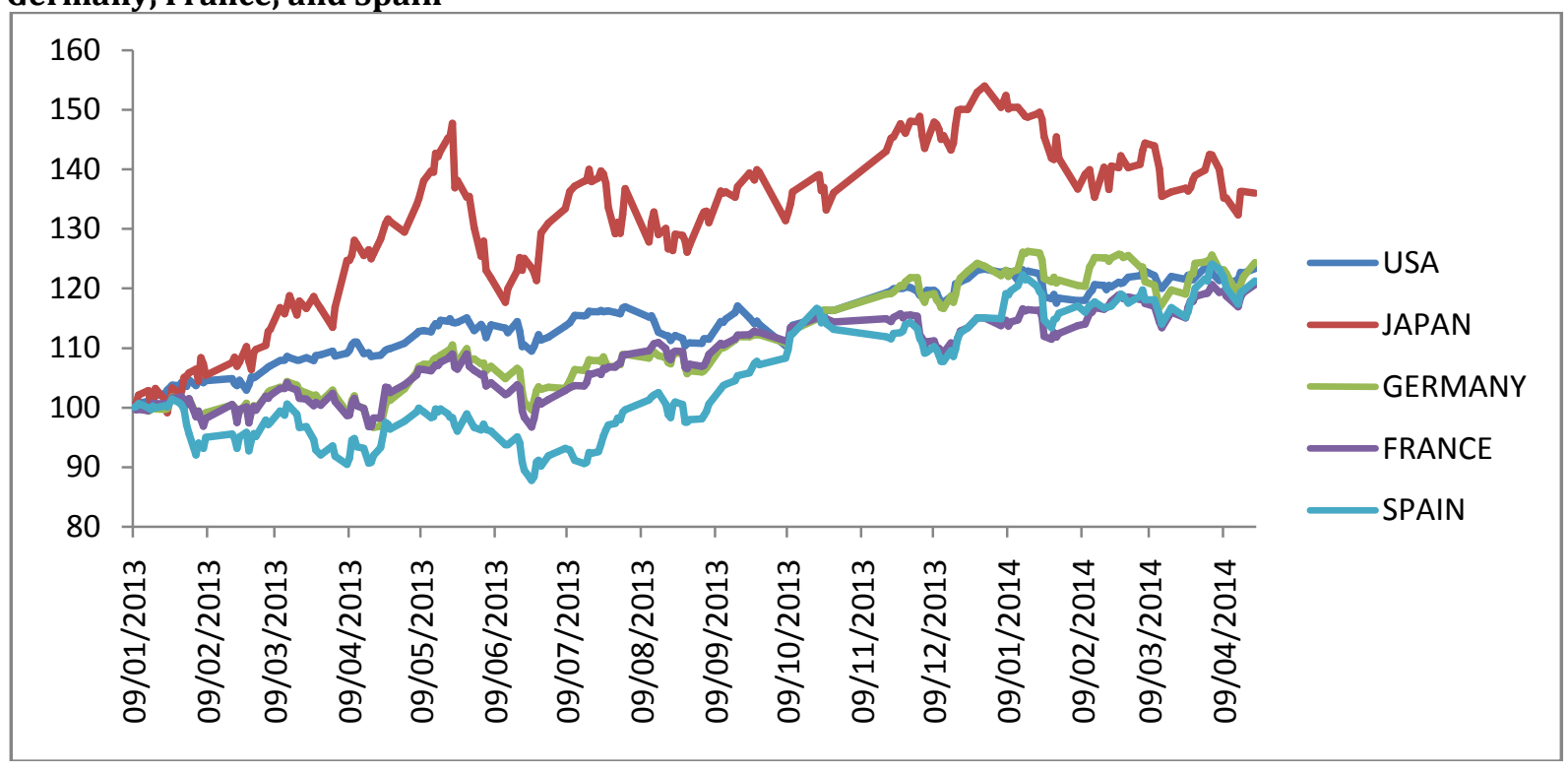

The Fed's Policies and Bond Index: The last variable we concentrate on is the bond index which is closely related to the interest rate of the country. We plot the bond indices of two giant emerging market economies, namely China and Russia. The figure speaks for itself; Russia recovers the decline of the first 8 months and closes the period with an increase of almost $40 \%$. China goes steady for about 8 months and then returns a stable increase until mid-December where the increase is about $40 \%$ and then closes with a $10 \%$ decrease to conclude in $30 \%$ overall increase. Note that almost all countries ask for international capital and there is a remarkable capital to flow where the investor feels like s/he should get the highest return without any risk. Countries willing to attract more capital have to speak with the interest they can pay.

Figure 4: The behavior of the bond index in response to Fed decisions, China and Russia

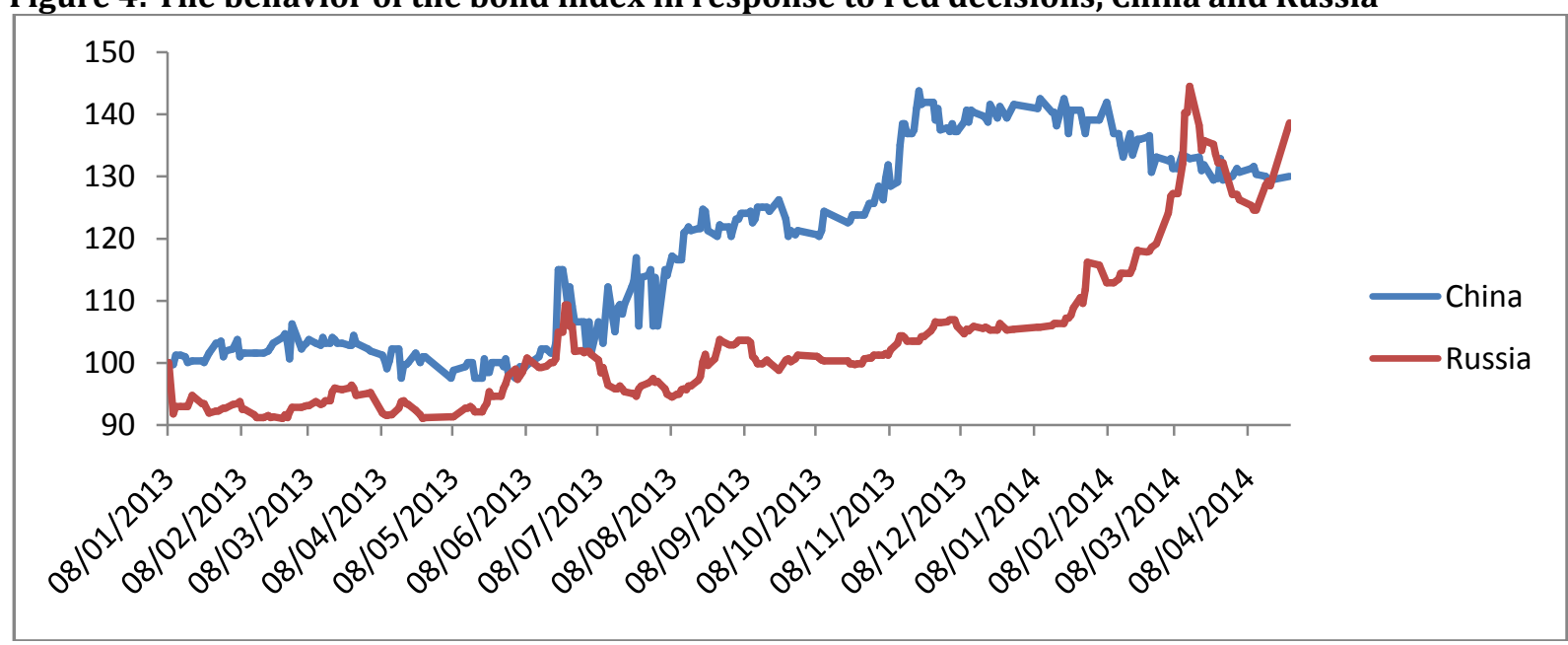

The bond indices of the developed countries follow somewhat diverse paths. Japanese index declines first and then increases to about $200 \%$ from where the index constantly decreases to below its initial value. Spanish index goes even lower to about $40 \%$ of its initial value. This does not necessarily mean that Spain is paying less to the capital invested. The point is that Spain had to pay so large before 2013 and the decline should be compared to that. Similarly French index is paying a bit more she used to pay at the beginning of 2013. The largest increase is observed for the US; indeed, US did pay almost 0 interest rate before 2013 and since they noticed signs of recovery the interest rate is let increase gradually though slightly. At the end of the period US pays about $220 \%$ of the initial value. Indeed, the US 10 -year bond 
interest rate came close to $3 \%$ which is too high compared to 0 real interest rate. Similarly, German bond index increased the initial value by about $10 \%$.

Figure 5: The behavior of the bond index in response to Fed decisions, USA, Japan, Germany, France, and Spain

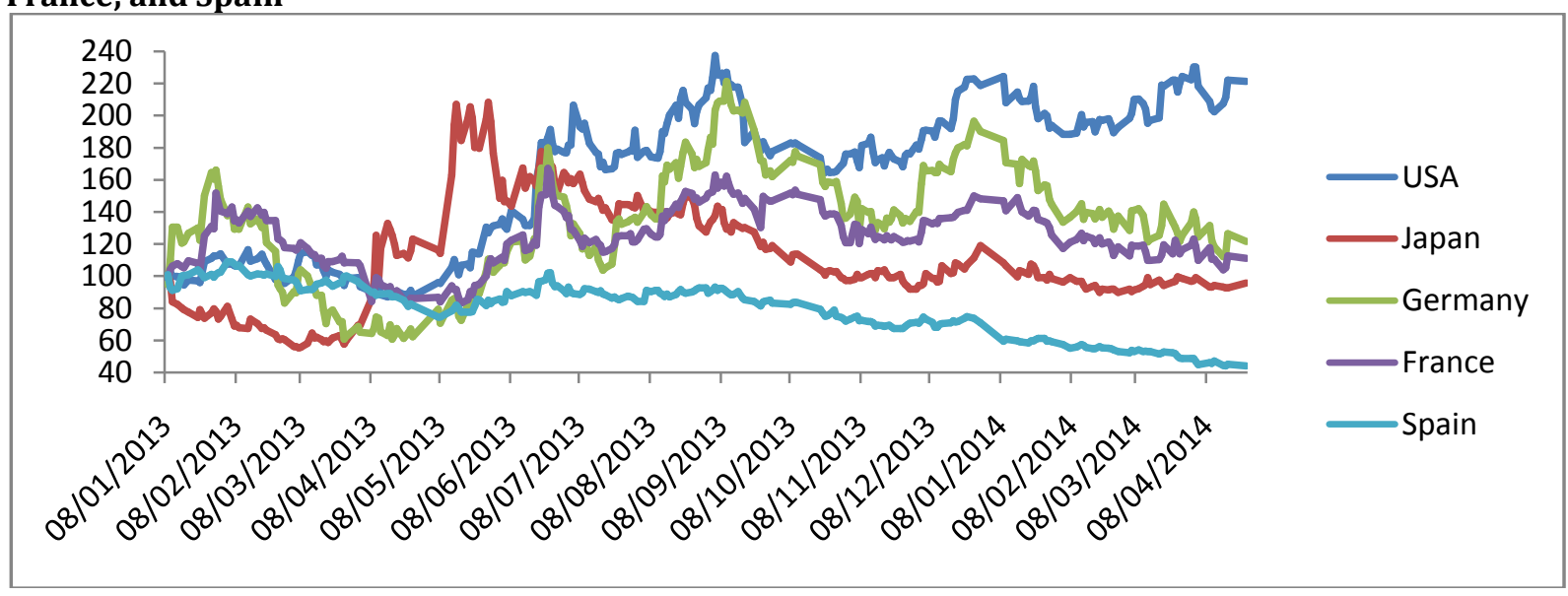

The Impact of the Fed Policies on Fragile Fives: The "Fragile Fives" describes five formerly fastgrowing emerging markets (Day, 2014). The Fragile Five have high inflation, weakening growth, and growing current-account deficits. It is interesting to note that the trajectories of all monetary units belonging to the Fragile Five are similar. Indeed, the Central Bank bureaucrats are professionals of monetary policies and are taking necessary measures to improve their positions.

Figure 6: The behavior of the exchange rates in response to Fed decisions, The Fragile Fives, New Turkish Lira, Brazilian Real, Indian Rupee, Indonesian Rupiah, South African Rand

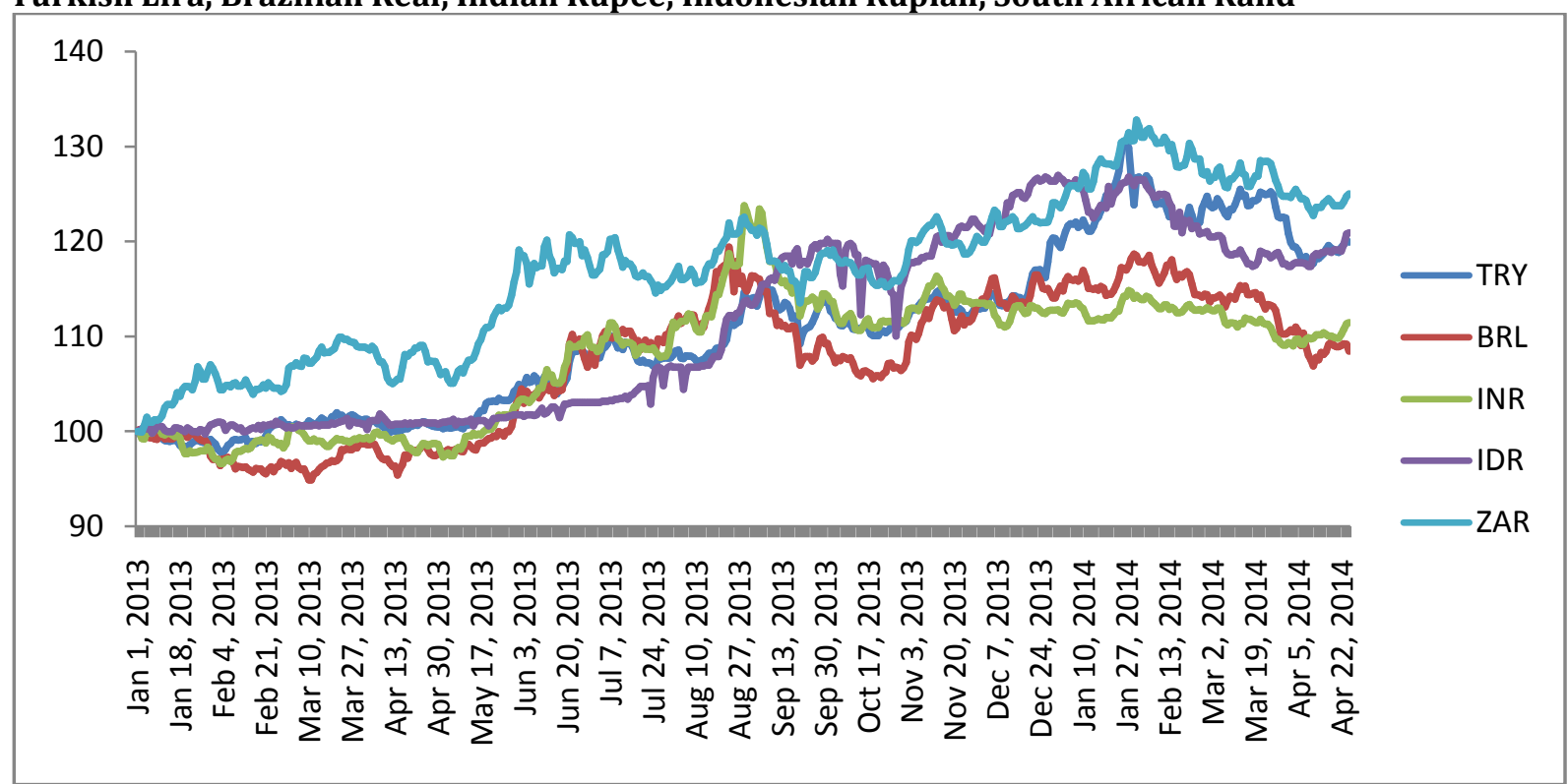

This process continues until the beginning of 2014 and then the currencies are appreciated slightly. One has to keep in mind that the main macroeconomic indicators behave interactively and the exchange rate is a very critical policy variable to keep track of inflation and trade deficit as well as current account balance. For instance, the depreciated TRY fuels inflation which is detrimental to the Turkish economy, while on the other hand, the appreciated TRY increases the trade deficit since Turkey has to trade for many of her sectors. Indeed, the Turkish policy makers have adopted the floating exchange rate and reserve the option of Central Bank intervention to the exchange rate market occasionally in case some indicators signal alarms. The policy variable announced by the Turkish Central Bank is the interest rate which in turn manipulates the exchange rate. All Fragile Five countries start depreciating their currencies in mid-2013 and until April 22, and currencies have been depreciated by about 10 to $25 \%$. 
The behavior of the stock exchange index in response to Fed decisions, Turkey, Brazil, India, Indonesia, and South Africa: Let's focus on the stock market indices of the Fragile Fives. From the beginning Turkey is the second country that ends up with a loss at the end of the period. Although Turkey achieves a 15\% increase in the first five months, the decline starts at May 2014 and the index closes with about $10 \%$ loss after several ups and downs over the range. South Africa follows a somewhat opposite path, it first decreases with low-attitude zigzags and is headed upwards from July 2014, in the end it achieves about $20 \%$ gain. Indonesia first jumps for first 5 months, declines for 4 months and then completes with about $10 \%$ increase. Besides, India oscillates with much lower wave lengths to end up with about $12 \%$ increase in the stock exchange. All Fragile Five countries have different routes in their stock exchange indices.

Figure 7: The behavior of the stock exchange index in response to Fed decisions, Turkey, Brazil, India, Indonesia, and South Africa

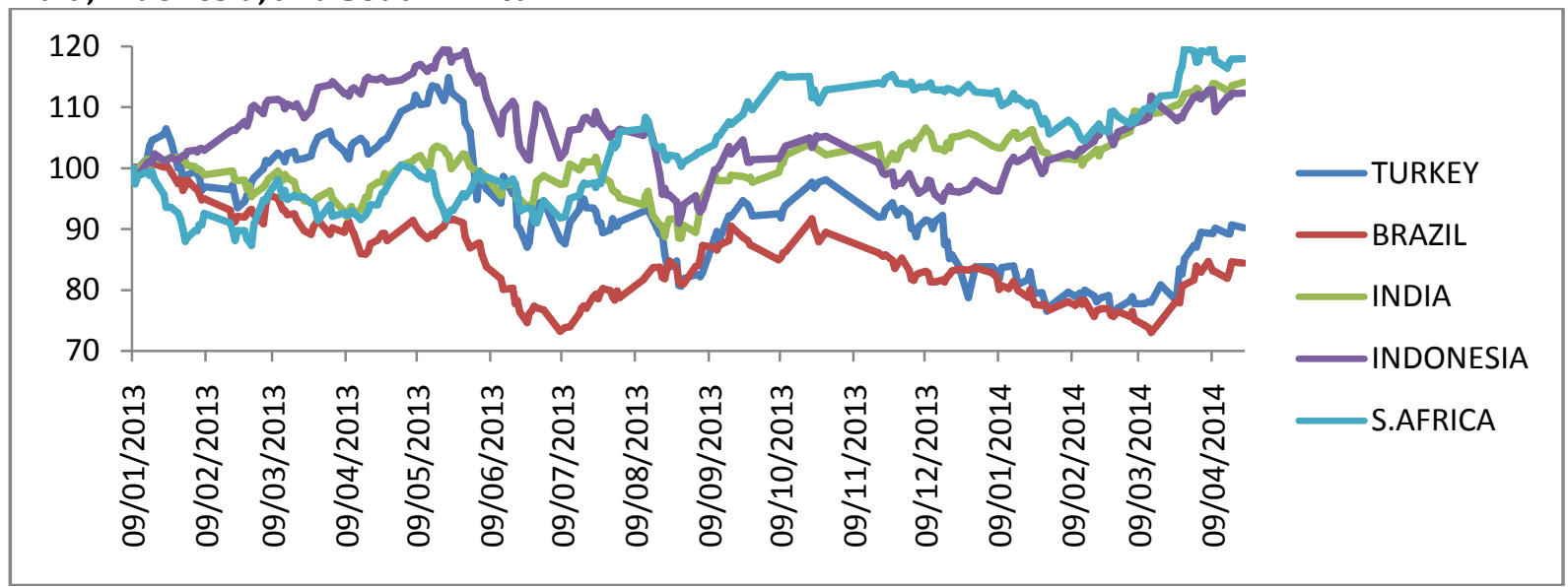

The Behavior of the Bond Index in Response to Fed Decisions, the Fragile Five: Coming to the bond indices of the Fragile Five, all have increased their bond indices were the lowest increase belongs to India. This giant emerging economy is followed by South Africa and Brazil for each of which there is about $40 \%$ increase. Note that the figures here are very low. Indeed, the real interest rate is sometimes negative and sometimes slightly higher than 0 . The emerging markets are in competition to attract capital and one feasible way is to increase the interest rate. The Indonesian Central Bank has helped support its currency by raising rates. Of the Fragile Five, South African central bank is the only that hasn't raised rates. According to Morgan Stanley analysts, India has lost fewer reserves than other countries in the Fragile Five (Day, 2014).

Figure 8: The behavior of the bond index in response to Fed decisions, Fragile Five

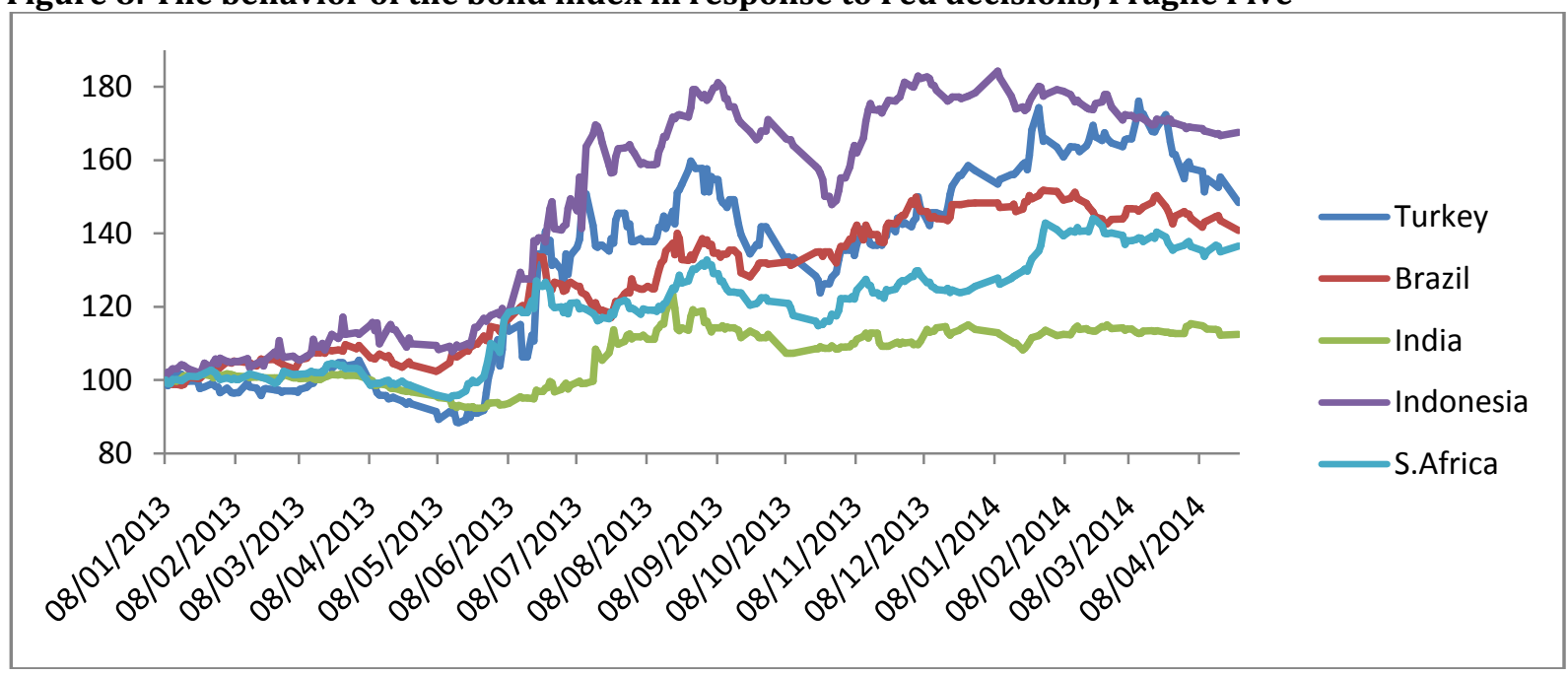

GARCH Framework to Investigate the Spillover Effect: It is reasonable to investigate the link among financial markets of countries since the shock striking a particular country can be transmitted to others 
over the globe. Such contagion is convenient to be explored with parallel movement of markets belonging to the countries of interest. In order to get the more precise insight over the spillover from the USA to the Fragile Fives, we make use of analytical tools. Although there a number of methods used in order to explore spillover ranging from Granger Causality to wavelet transform, we adopt the GARCH framework as the majority of the researchers on the topic did. One of the pioneering papers on such applications is Hamao et al. (1990) where they explore the volatility spillover between the US and Japan. They document that the spillover is running from the US to Japan with the help of the GARCH specification. In a similar study, Abou-Zaid (2011) investigates the international transmission of daily stock index volatility movements from the US and UK to selected MENA emerging markets in multivariate GARCH in mean framework. Similarly, Bhar and Nikolova (2007) make use of GARCH in mean to question whether the world index returns have significant influence upon the variance of returns seen across Brazil, Russia and India. Such GARCH techniques are extensively used in the literature to figure out spillover effects of various factors. Alom et al. (2011), for instance, employed multivariate T-GARCH model to assess the mean and volatility spillover effects of food prices among a number of Asian and Pacific countries where they documented strong evidence of mean spillover effects from the USA food price returns to all other markets.

We construct the GARCH in mean model to decide on the spillover effect from the USA to the Fragile Fives countries. A typical GARCH model includes mean and variance equations that we specify as:

$$
\begin{aligned}
& R_{i, t}=\alpha_{i, 0}+\beta_{i, 1} R_{i, t-1}+\vartheta h_{i, t}+\omega_{U S} Y_{U S, t}+\varepsilon_{i, t}, \varepsilon_{i, t} \sim N\left(0, h_{i, t}\right) \\
& h_{i, t}=a_{i, 0}+b_{i, 1} h_{i, t-1}+c_{i, 2} \varepsilon_{i, t-1}^{2}+\delta_{U S} \varepsilon_{U S, t}^{2}
\end{aligned}
$$

Where $R_{i, t}$ is the daily return of country belonging to the Fragile Fives (i= Brazil, India, Indonesia, South Africa and Turkey), $\varepsilon$ is the error and $h_{i, t}$ is the GARCH term. $Y_{U S, t}$ in the mean equation is placed to examine the mean spillover effect of US stock index return over the Fragile Five and similarly, $\varepsilon_{U S, t}^{2}$ is to test for the existence, sign, and magnitude of the volatility spillover. The same equation is estimated for the base equation of the US without $Y_{U S, t}$ and $\varepsilon_{U S, t}^{2}$ terms. Data are provided from Investing.com and Yahoo Finance and all calculations are executed with Eviews. Table 1 is prepared to report the estimates of all parameters including $\omega$ and $\delta$ to decide on mean and volatility spillover, respectively.

\begin{tabular}{|c|c|c|c|c|c|c|c|c|c|c|}
\hline \multirow{3}{*}{ Parameters } & \multicolumn{10}{|c|}{ Spillover Effects } \\
\hline & \multicolumn{2}{|l|}{ Brazil } & \multicolumn{2}{|l|}{ India } & \multicolumn{2}{|l|}{ Indonesia } & \multicolumn{2}{|c|}{ South Africa } & \multicolumn{2}{|l|}{ Turkey } \\
\hline & Estimate & Prob. & Estimate & Prob. & Estimate & Prob. & Estimate & Prob. & Estimate & Prob. \\
\hline$\alpha$ & -0.003469 & 0.4695 & -0.004771 & 0.2921 & 0.003611 & 0.1914 & -0.002449 & 0.3323 & -0.000254 & 0.9530 \\
\hline$\beta$ & 0.015013 & 0.8457 & 0.031476 & 0.6891 & 0.011273 & 0.8802 & -0.000700 & 0.9932 & -0.000547 & 0.9945 \\
\hline$\vartheta$ & 0.166833 & 0.6371 & 0.467130 & 0.2770 & -0.201239 & 0.3936 & 0.343987 & 0.2344 & -0.000182 & 0.9994 \\
\hline$\omega$ & 0.439385 & 0.0006 & 0.409154 & 0.0001 & 0.190541 & 0.2291 & 0.407550 & 0.0000 & 0.518591 & 0.0252 \\
\hline$a$ & 0.000010 & 0.1777 & 0.000003 & 0.4843 & 0.000044 & 0.0032 & 0.000007 & 0.2049 & 0.000077 & 0.0310 \\
\hline$b$ & 0.881539 & 0.0000 & 0.874691 & 0.0000 & 0.298357 & 0.0270 & 0.659962 & 0.0000 & 0.172740 & 0.0464 \\
\hline$c$ & -0.003522 & 0.9149 & 0.052996 & 0.2020 & 0.067221 & 0.3289 & 0.132333 & 0.0462 & 0.133063 & 0.0464 \\
\hline$\delta$ & 0.233046 & 0.0849 & 0.088420 & 0.1505 & 1,377246 & 0.0000 & 0.177198 & 0.0354 & 4,415879 & 0.0000 \\
\hline
\end{tabular}

Table 1: Stock Exchange Market's Spillover Effects from USA to Fragile Five Countries

Low p-values of $\omega$ for all but Indonesia indicate mean spillover from the US to four The Fragile Fives countries. Similarly, p-values for $\delta$ are less than $10 \%$ for all but India, indicating the volatility spillover from the US to four Fragile Fives countries. Indeed, India's p-value of about $15 \%$ can be interpreted as significant with $15 \%$ probability of Type I error. All in all, both mean and volatility spillover are documented from the USA to almost all The Fragile Fives countries.

\section{Conclusion and Policy Implications}

The Fragile Five are heavily dependent on short term capital inflows in order to finance both their economic growth and current account deficits. Therefore the Fragile Fives are sharply affected from 
Bernanke's public statement in mid May 2013. The current Fed Chair, Janet Yellen also has following the same policy. Firstly we found that all of the Fragile Fives' currencies have with much larger exchange rate depreciation in mid-2013. Their central banks have intervened by selling foreign exchange swaps and raising benchmark interest rates except South Africa. This process continued until the beginning of 2014 and then their currencies are appreciated slightly. Secondly, their stock exchange indices are decreased from January to July 2013 at different rates. This decline is reversed at July 2013 and the upward turn continued until October 2013. Finally, it is observed that increases in bond indices led to raising inflation rates and decreasing economic growth as well as re-pricing of risk at the global level. Fed tapering policies have differently impacted on fast growing emerging markets due to and their structural weakness.

In particular, the findings of this study show the importance of strong domestic macroeconomic indicators for sustainable economic growth. Therefore policy makers should take necessary measures in order to fight their twin deficits and their weak fundamentals. In particularly, they should carry out domestic reforms in order to restore confidence and stability. If they have adequate foreign reserves, they could sell dollar in their markets to prevent their exchange-rate depreciation. Besides, deregulation of capital flows and incentives for foreign direct investment might help them against global financial tightness. In addition, their strong domestic institutions and independent central banks might keep them away from uncertainties and thus global financial risks. Finally, we have documented the mean and volatility spillover effect of stock exchange returns on Fragile Five returns.

\section{References}

Abou-Zaid, A. S. (2011). Volatility Spillover Effects in Emerging MENA Stock Markets. Review of Applied Economics, 7(1-2).

Albu, L. L., Lupu, R., Călin, A. C. \& Popovici, O. C. (2014). The Effect of ECB's Quantitative Easing on Credit Default Swap Instruments in Central and Eastern Europe. Procedia Economics and Finance, 8, 122-128.

Alom, F., Ward, B. \& Hu, B. (2011). Cross country mean and volatility spillover effects of food prices: multivariate GARCH analysis. Economics Bulletin, 31(2), 1439-1450.

Barkar, M. (2013). Morgan Stanley Presents: 'The Fragile Five' - the Most Troubled Currencies in Emerging Markets. Business Insider, Retrieved from http://www.businessinsider.com/morganstanley-fragile-5-emerging-markets-2013-9?op=1\#ixzz31VbPPBZR,

Burns, A., Kida, M., Lim, J., Mohapatra, S. \& Stocker, M. (2014). Unconventional monetary policy normalisation and emerging-market capital flows. Retivered from http://www.voxeu.org/article/tapering-and-emerging-market-capital-flows

Bhar, R. \& Nikolova, B. (2007). Analysis of mean and volatility spillovers using BRIC countries, regional and world equity index returns. Journal of Economic Integration, 22(2), 369-381.

Carr, D. (2013). QE... Taper...? Does Post-Taper Policy Need a'Big Bang'Return to Normalcy? Taper. Retrieved from http://papers.ssrn.com/sol3/papers.cfm?abstract_id=2349826

Clarida, R., Gali, J. \& Gertler, M. (2002). A simple framework for international monetary policy analysis. Journal of Monetary Economics, 49(5), 879-904.

Day, M. (2014). After Tough Year for Emerging Markets, Fates of 'Fragile Five' Diverge. The Wall Street Journal, Retrieved from http://blogs.wsj.com/moneybeat/2014/03/19/fates-of-fragile-fivediverge-as-emerging-markets-face-tough-year/

D’Amico, S., English, W. B., Lopez-Salado, D. \& Nelson, E. (2012). The Federal Reserve's Large-Scale Asset Purchase Programs: Rationale and Effects. Working Paper, Federal Reserve Board, p. 1-58.

Doh, T. (2010). The efficacy of large-scale asset purchases at the zero lower bound. Federal Reserve Bank pp:1-122of Kansas City Economic Review, 95(2), 5-34.

Eichengreen, B. (2013). Does the Fed Care About the Rest of the World? University of California, Berkeley.

Eichengreen, B. \& Gupta, P. (2014). Tapering Talk: The Impact of Expectations of Reduced Federal Reserve Security Purchases on Emerging Markets. Retrieved from http://mprabuniMuenchende/53040/Ations.

Fratzscher, M., Duca, M. L. \& Straub, R. (2013). On the international spillovers of US quantitative easing. European Central Bank Working Paper Series, 1557, 1-64.

Gagnon, J., Raskin, M., Remache, J. \& Sack, B. (2011). The financial market effects of the Federal Reserve's large-scale asset purchases. International Journal of Central Banking, 7(1), 3-43.

Gökay, B. (2009). The 2008 World Economic Crisis: Global Shifts and Faultlines. Centre for Research on Globalization, 15(1). 
Hamao, Y., Masulis, R. W. \& Ng, V. (1990). Correlations in price changes and volatility across international stock markets. Review of Financial studies, 3(2), 281-307.

Hancock, D. \& Passmore, W. (2011). Did the Federal Reserve's MBS purchase program lower mortgage rates? Journal of Monetary Economics, 58(5), 498-514.

Herbst, A. F., Wu, J. S. \& Ho, C. P. (2014). Quantitative easing in an open economy-Not a liquidity but a reserve trap. Global Finance Journal, 25(1), 1-16.

Hoffmann A. (2014). Zero-Interest Rate Policy And The Unintended Consequences In Emerging Markets. International Centre for Economic Research, Working Paper No.2/2014 http://www.icer.it/docs/wp2014/ICERwp02-14.pdf

Kimura, T. \& Nakajima, J. (2013). Identifying Conventional and Unconventional Monetary Policy-Shocks. Retrieved from http://www.voxeu.org/article/identifying-conventional-and-unconventionalmonetary-policy-shocks.

Krishnamurthy, A. \& Vissing-Jorgensen, A. (2011). The effects of quantitative easing on interest rates: channels and implications for policy (No. w17555). National Bureau of Economic Research. Retrieved from .thttp://www.nber.org/papers/w17555

Mishkin, F. S. (2000). Inflation targeting in emerging market countries (No. w7618). National Bureau of Economic Research.

Nechio, F. (2014). Fed tapering news and emerging markets. FRBSF Economic Letter, 06. Retrieved from http://www.frbsf.org/economic-research/publications/economic-letter/2014/march/private credit-public-debt-financial-crisis/el2014-06.pdf

Obstfeld, M. \& Rogoff, K. (2002). Global implications of self-oriented national monetary rules. Quarterly Journal of Economics, 3, 503-535.

Rasmus, J. (2013). From Taper Tantrum \& Token Taper to Taper Tomorrow - Fed Policy in Crisis. Retrieved from http://jackrasmus.com/tag/interest-rates/.

Serin, Z. \& Oktay, B. (2014). Global Governance and Turkey's Position in the Post-Global Crisis Period. Journal of Social and Development Sciences, 5(1), 7-13.

Subramanian, A. (2014). International Impacts of the Federal Reserve's Quantitative Easing Program. Retrieved from http://www.cgdev.org/publication/international-impacts-federalreserve\%E2\%80\%99s-quantitative-easing-program

Taylor, J. B. (2012). Monetary policy rules work and discretion doesn't: A tale of two eras. Journal of Money, Credit and Banking, 44(6), 1017-1032.

Wood, C. (2013). Markets Addicted To QE. The Economic times. Retrieved from http://articles.economictimes.indiatimes.com/2013-11-18/news/44202461_1_investmentcycle-curre. 